\title{
PENDIDIKAN KARAKTER DALAM PEMBELAJARAN PADA MAHASISWA CALON GURU MATEMATIKA
}

\author{
Yudi Darma $^{1}$, Utin Desy Susiaty ${ }^{2}$, Dona Fitriawan ${ }^{3}$ \\ Prodi Pendidikan Matematika, Fakultas Pendidikan MIPATEK, IKIP PGRI Pontianak ${ }^{1,2,3}$ \\ Email : yudidarmamtk@gmail.com ${ }^{1}$
}

\begin{abstract}
Abstrak
Tujuan penelitian yaitu untuk mengetahui: 1) calon guru matematika merencanakan pendidikan karakter pada pembelajaran; 2) calon guru matematika melaksanakan pendidikan karakter pada pembelajaran; 3) calon guru matematika menilai pendidikan karakter pada pembelajaran. Penelitian deskriptif kualitatif adalah jenis dalam penelitian ini. Subjek penelitian dalam penelitian ini adalah tenaga pengajar IKIP PGRI Pontianak khsuusnya program studi Pendidikan Matematika. Berdasarkan hasil penelitian dapat disimpulkan sebagai berikut. 1) Calon guru matematika merencanakan pendidikan karakter dengan baik dan diinternalisasi dalam kurikulum KKNI serta dirancang sesuai dengan indikator-indikator yang ada pada panduan SNP-PT. 2) Calon guru matematika melaksanakan pendidikan karakter dengan baik. 3) Calon guru matematika menilai pendidikan karakter dengan sangat baik sebagai perbaikan karakter di lingkungan prodi.
\end{abstract}

Kata Kunci: Pendidikan Karakter, Perencanaan, Pelaksanaan, Penilaian

Abstract

The aim of the research is to study: 1) how prospective mathematics teachers plan character education in learning; 2) how prospective mathematics teachers carry out character education in learning; 3) how prospective mathematics teachers assess character education in learning. The research is a qualitative descriptive research. The research subjects are IKIP PGRI Pontianak teachers, especially those in Mathematics Education study program. Based on the results of the research, it can be concluded that. 1) Prospective mathematics teachers plan well the character education, internalize it in the KKNI curriculum and design it according to the indicators set in the SNP-PT guidelines. 2) Prospective mathematics teachers carry out well the character education. 3) Prospective mathematics teachers assess very well the character education as an improvement in character in the study program environment.

Keywords: Character Education, Planning, Implementation, Assessment

\section{PENDAHULUAN}

Dua aspek kombinasi pelajaran yaitu siswa belajar sesuai dengan tujuan yang akan dilaksanakan oleh siswa, guru memberikan pelajaran berfokus pada apa yang harus diajarkan merupakan suatu proses pembelajaran. Proses pembelajaran berlangsung, kedua aspek kombinasi tersebut harus dilaksanakan pada saat terjadi komunikasi pembelajaran antara guru dengan siswa di dalam kelas. Hal tersebut juga berlaku pada mahasiswa dan dosen. Dengan kata lain, menurut Suherman dalam [1] terjadinya proses komunikasi dua arah antara guru dan siswa serta perubahan sikap dalam pembelajaran. Dengan begitu dalam pembelajaran selalu terikat dua hal penting yaitu konsep-konsep komunikasi baik secara konseptual maupun operasional dan perubahan sikap.

Suherman dalam [1] menyatakan bahwa terjadinya aliran dua arah pertukaran informasi antara satu sama lain para partisipan/siswa merupakan pendefinisian dari komunikasi. Hal tersebut mendefinisikan bahwa komunikasi hanya bisa terjadi antar minimal dua individu. Dimana dalam pembelajaran, pendidik dan peserta didiklah yang melakukan proses komunikasi tersebut. Peran utama dari komunikasi tersebut adalah seorang tenaga pendidik dan peserta didik sebagai peran utama komunikan. Tenaga pendidik dan 
peserta didik akan bertukar peran secara praktiknya pada saat proses pembelajaran berlangsung [1].

Pencapaian tujuan dari pembelajaran pada proses pembelajaran tergantung dari pelaku dalam proses pembelajaran itu sendiri yaitu guru dan siswa secara bersama-sama. Halhal yang bermanfaat seperti fakta, keterampilan, nilai, konsep dan hasil belajar yang diinginkan dengan mudah dapat dipelajari oleh siswa dalam proses pembelajaran merupakan pembelajaran yang efektif (Wragg dalam [1]). Dari uraian di atas terlihat bahwa proses pembelajaran bukan sekedar transfer ilmu dari guru kepada siswa atau dosen kepada mahasiswa, melainkan suatu proses kegiatan, yaitu terjadi interaksi antara guru dengan siswa serta antara siswa dengan siswa atau antara dosen dengan mahasiswa serta antara mahasiswa dengan mahasiswa. Pembelajaran hendaknya tidak menganut paradigm transfer of knowledge, yang mengandung makna bahwa siswa merupakan objek dari belajar. Namun, kegiatan memilih, menetapkan serta mengembangkan metode guna mencapai hasil pembelajaran yang diinginkan merupakan upaya dalam membelajarkan siswa. Kegiatan tersebut berdasarkan pada situasi dan kondisi pembelajaran yang sudah ada. Upaya dalam memberikan pelajaran kepada siswa maupun mahasiswa merupakan istilah pembelajaran yang mempunyai hakekat perencanaan atau perancangan (disain). Pada proses pembelajaran, tujuan dalam pembelajaran akan dicapai dengan cara siswa/mahasiswa harus melakukan interaksi bukan hanya dengan guru/dosen sebagai salah satu sumber dalam belajar, melainkan dengan keseluruhan sumber belajar. Oleh karena itu pembelajaran menaruh perhatian pada "bagaimana membelajarkan siswa/mahasiswa" dan bukan pada "apa yang dipelajari siswa/mahasiswa" [1].
Setiap mahasiswa pada prinsipnya mengikuti pembelajaran di jenjang lebih tinggi yaitu di lingkungan pendidikan tinggi. Mahasiswa merupakan peserta didik yang melakukan interaksi dengan dosen dan antar mahasiswa untuk mencapai tujuan pembelajaran. Menurut [2] mahasiswa pada saat ini merupakan harapan bagi masyarakat karena dapat melakukan perubahan di masyarakat (Agent of Change). Individu yang harus dapat mengimplementasikan kompetensi dalam bidang keilmuannya pada akselerasi perubahan dunia ke arah yanag lebih baik adalah mahasiswa yang juga merupakan kaum muda sebagai salah satu potensi dalam masyarakat. Karena mahasiswa adalah figure yang sangat penting dalam melakukan pembangunan bangsa kearah yang lebih maju serta menjadi alat perubahan dan control terhadap suatu kebijakan yang terjadi dalam pemerintahan.

Jalur, jenjang dan satuan pendidikan tertentu pada proses pembelajaran merupakan usaha mahasiswa dalam mengembangkan potensi dirinya sebagai peserta didik. Pembimbingan kemahasiswaan sebagai peserta didik dalam proses pendidikan merupakan usaha dalam rangka mencapai tujuan pendidikan nasional dan merupakan perwujudan mahasiswa sebagai subjek didik di pendidikan tinggi. Mahasiswa merupakan aset bangsa, sebagai intelektual muda calon pemimpin masa depan [2].

Mahasiswa merupakan peserta didik yang memiliki berbagai macam karakter. Menurut [3] karakter seorang individu terbentuk sejak dia kecil karena pengaruh genetic dan lingkungan sekitar. Perilaku individu yang tercermin dalam kehidupan sehari-hari serta cara pandangnya secara sadar maupun tidak disadari dipengaruhi oleh proses pembentukan karakter dalam individu tersebut. Salah satu sumber daya yang penting dan merupakan lembaga 
pendidikan tinggi adalah Universitas. Termuatnya pendidikan karakter secara jelas dalam penyusunan kurikulum sangatlah penting. Kenyataannya, mahasiswa terdorong menjadi mahasiswa yang pragmatis dalam menggapai tujuannya dikarenakan factor singkatnya waktu studi serta biaya pendidikan yang tergolong mahal. Hal ini pun berdampak kepada semakin sedikitnya kegiatan social yang dapat diikuti oleh mahasiswa karena dituntut konsentrasi yang penuh oleh mahasiswa dalam kegiatan akademik. Dorongan untuk berinteraksi secara social dengan sesama sangat kurang, padahal ini sangat penting dalam pembentukan karakter. Pembentukan karakter sangat penting untuk mahasiswa terutama mahasiswa sebagai calon guru harus memiliki karakter yang dapat menjadi contoh bagi anak didiknya kelak.

Hal ini sejalan dengan penelitian yang dilakukan oleh [4] yang menyatakan bahwa guna membentuk dan membangun mahasiswa yang memiliki pribadi yang berkarakter sesuai dengan Ideologi Negara Indonesia serta memperkokohnya, maka diperlukan penyelenggaranaan pendidikan karakter pada perguruan tinggi. Pertumbuhan individu menjadi manusia yang seutuhnya dapat terjadi dengan adanya pendidikan karakter yang dimulai sejak dini [3]. Akan tetapi, perguruan tinggi sebagai pendidikan tertinggi pada seorang individu perlu menyelenggarakan pendidikan karakter walaupun pendidikan dasar belum mengakomodasinya. Sangat penting bagi perguruan tinggi untuk menciptakan lulusan yang bukan hanya siap secara akademis namun juga berkarakter baik dengan cara melakukan pembinaan karakter pada mahasiswanya. Menurut [5] diharapkan dengan pendidikan karakter akan menghasilkan manusia Indonesia yang berkarakter sesuai dengan tujuan dan citacita pendidikan.
Melihat kondisi yang terjadi tersebut, peneliti berkeinginan untuk melakukan analisis terhadap pendidikan karakter dalam pembelajaran pada mahasiswa calon guru khususnya mahasiswa Program Studi Pendidikan Matematika IKIP PGRI Pontianak untuk melihat sejauh mana pendidikan karakter diberikan selama proses pembelajaran dalam perkuliahan. Penelitian ini diharapkan dapat memberikan informasi lebih mendalam kepada pihak terkait dalam menganalisis pendidikan karakter dalam pembelajaran pada mahasiswa calon guru khususnya mahasiswa Program Studi Pendidikan Matematika IKIP PGRI Pontianak.

\section{METODE}

Penelitian ini termasuk penelitian deskriptif kualitatif yang bertujuan untuk mengetahui hasil analisis pendidikan karakter dalam pembelajaran pada mahasiswa calon guru matematika. Menurut [6] metode penelitian yang berlandaskan pada filsafat postpositivisme, yang digunakan untuk meneliti pada kondisi obyek yang alamiah, dimana peneliti sebagai instrumen kunci, purposive atau snowball adalah cara pengambilan sampel sumber data, teknik pengumpulan data dengan trianggulasi (gabungan), analisis data bersifat induktif/kualitatif, serta penekanan makna daripada generalisasi pada hasil penelitian kualitatif merupakan metode penelitian kualitatif. Tenaga pengajar pada program studi Pendidikan Matematika IKIP PGRI Pontianak merupakan subjek pada penelitian ini. Penentuan subjek ini berdasarkan info dari program studi pendidikan matematika IKIP PGRI Pontianak. Penelitian ini dilaksanakan di IKIP-PGRI Pontianak, tepatnya pada Program Studi Pendidikan Matematika tahun akademik 2016/2017 Jalan Ampera no 8 Pontianak Kalimantan Barat.

Teknik pengumpul data dalam penelitian ini adalah teknik observasi, teknik wawancara 
dan teknik dokumentasi dengan alat pengumpul datanya berupa lembar observasi, pedoman wawancara serta dokumentasi perangkat pembelajaran dan soal. Dokumentasi perangkat pembelajaran dan soal ini diperoleh dari dosen Program Studi Pendidikan Matematika. Observasi dan wawancara dilakukan kepada subjek penelitian yaitu dosen-dosen Program Studi Pendidikan Matematika IKIP PGRI Pontianak pada saat melaksanakan pembelajaran di kelas.

\section{HASIL DAN PEMBAHASAN}

Berdasarkan hasil analisis angket observasi bedah instrumen serta wawancara dari 2 (dua) orang dosen pengelola dan 12 (dua belas) dosen Program Studi Pendidikan Matematika IKIP PGRI Pontianak, maka dapat dipaparkan implementasi pendidikan karakter yaitu sebagai berikut.

Pada proses calon guru matematika merencanakan pendidikan karakter pada pembelajaran, berdasarkan hasil dari angket observasi bedah instrument dari perangkat pembelajaran 12 (dua belas) orang dosen dapat dilihat bahwa perencanaan pendidikan karakter sudah diinternalisasi dalam kurikulum pembelajaran yang dimulai dari mengkaji Standar Kompetensi (SK), Kompetensi Dasar (KD) dalam setiap mata pelajaran, mencantumkan nilai-nilai karakter pada silabus, pembuatan silabus mengacu pada standar isi, menjalankan nilai-nilai karakter yang tercantum dalam silabus, silabus mencantumkan nilai-nilai budaya serta karakter bangsa, dan di dalam RPP mencantumkan nilai-nilai karakter. Berdasarkan hasil wawancara dapat dilihat bahwa penanaman pendidikan karakter diinternalisasi dalam kurikulum KKNI dan dirancang sesuai dengan indikator-indikator yang ada pada panduan SNP-PT. Selain itu, penanaman pendidikan karakter dimasukkan dalam proses pembelajaran dikarenakan karakter seseorang tidak hanya dilihat dari segi kelimuannya saja, tapi prakteknya dalam kehidupan sehari-hari.

Pada proses calon guru matematika melaksanakan pendidikan karakter pada pembelajaran, berdasarkan hasil dari angket observasi bedah instrument dari perangkat pembelajaran 12 (dua belas) orang dosen dapat dilihat bahwa pelaksanaanpendidikan karakter sudah diimplementasi dalam pembelajaran yang dimulai dari Dosen memberikan motivasi saat pembelajaran berlangsung, menekankan mahasiswanya untuk aktif selama proses pembelajaran, memberikan bantuan kepada mahasiswanya yang mengalami kesulitan dalam mengaktualisasikan nilai-nilai karakter, memeriksa kebersihan serta kerapihan mahasiswa selama memasuki lingkungan kampus/Prodi, memeriksa kebersihan serta kerapihan mahasiswa selama memasuki lingkungan kampus/Prodi, menyediakan tempat sampah di lingkungan kampus/Prodi, berdoa sebelum dan/atau setelah pelajaran, serta terdapat budaya salam di lingkungan kampus/Prodi. Namun, masih ada impelementasi pendidikan karakter yang tidak dilaksanakan kepada seluruh mahasiswa Program Studi Pendidikan Matematika yaitu melaksanakan upacara bendera dan ibadah khusus secara bersama. Berdasarkan hasil wawancara dapat dilihat bahwa pelaksanaan pendidikan karakter sudah berjalan dengan baik walaupun belum secara keseluruhan dikarenakan terdapat kendala di dalam penanaman pendidikan karakter seperti waktu yang sedikit dalam penanaman karakter khususnya terkait dengan beban SKS perkuliahan yang harus diiringi pendidikan karakter saat mengajar di kelas.

Pada proses calon guru matematika menilai pendidikan karakter pada pembelajaran, berdasarkan hasil dari angket observasi bedah instrument dari perangkat pembelajaran 12 (dua belas) orang dosen dapat dilihat bahwa penilaian 
pendidikan karakter sudah diimplementasi dalam pembelajaran yang dimulai dari peneguran mahasiswa yang melanggar tata tertib kampus/Prodi, mengadakan sumbangan saat ada bencana atau berita duka, memberikan pujian terhadap mahasiswa yang berprestasi, memberikan reward terhadap mahasiswa yang berprestasi, serta menindak, menghukum, memberikan sanksi kepada mahasiswa yang melanggar tata tertib kampus/Prodi.

Berdasarkan hasil wawancara dapat dilihat bahwa penilaian pendidikan karakter dilakukan dengan tujuan untuk memberikan gambaran yang jelas mengenai pendidikan karakter sebagai perbaikan sikap yang menurun dan dasar perbaikan-perbaikan karakter di lingkungan mahasiswa prodi pendidikan matematika IKIP PGRI Pontianak. Oleh sebab itu penilaian pendidikan karakter dilaksanakan di dalam semua aspek akademik maupun administrasi serta di dalam maupun di luar prodi pendidikan matematika.

Adapun materi atau nilai-nilai yang dinilai dalam pendidikan karakter antara lain kejujuran, kedisiplinan, tanggung jawab, menghargai, peduli, berupaya untuk bertindak benar, memiliki daya juang, santun, sopan. Teknik yang digunakan dalam proses penilaian pendidikan karakter di kampus/Prodi melalui aktivitas ujian, proses pembelajaran, layanan bimbingan dan konsultasi, kegiatan mahasiswa baik di dalam aktivitas pembelajaran maupun di luar kelas dan berdasarkan sikap. Namun, penilaian pendidikan karakter di kampus/Prodi belum didukung dengan perangkat/instrumen yang jelas serta pemberian reward/sanksi.

Berdasarkan hasil jawaban responden berkenaan dengan perencanaan, pelaksanaan dan penilaian pendidikan karakter di ingkungan Program Studi Pendidikan Matematika, berikut gambar 1.1 dapat dilihat kesesuaian dari ketiga aspek tersebut yang menjadi satu-kesatuan terintegrasi dalam proses perkuliahan:

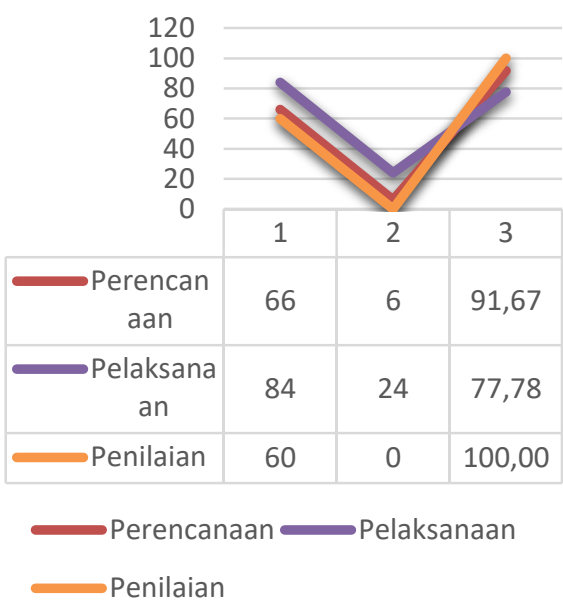

\section{Gambar 1. Kesesuaian Aspek Karakter}

Berdasarkan gambar 1, bahwasanya pada aspek perencanaan dan penilaian berada pada kategori sangat baik, sedangkan pada aspek pelaksanaan dengan kategori baik. Secara umum dengan hasil sebesar $89,82 \%$ kesesuaian ketiga aspek tersebut berada pada kategori sangat baik. Oleh sebab itu hal-hal yang sudah diperoleh dalam katgori baik ke atas untuk dapat dipertahankan dan terus ditingkatkan, khususnya yang dapat menjadi perhatian pada aspek pelaksanaan yang berkenaan dengan upacara bendera dan pelaksanaan ibadah untuk kiranya dapat dijadikan sebagai momentum pembinaan yang dapat menjadi agenda untuk mengembangkan dan menguatkan nilai-niai karakter.

Perencanaan pendidikan karakter dilaksanakan dalam kegiatan belajar mengajar maupun kegiatan keorganisasian dan/atau ekstrakurikuler. Karena ruang belajar mahasiswa tidak hanya di dalam kelas, akan tetapi juga di luar kelas. Pendidikankaraktermerupakan sebuah proses yang panjang, dimulai dari awal mahasiwa masuk sampai selesa, 
pendidikan karakter dilaksanakan melalui semua mata kuliah, pengembangan diri, kegiatan ekstrakurikuler dan manajemen institusi yang saling bersinergi.

Pada proses pembelajaran aktif nilai-nilai karakter pendidikan bangsa bukan hanya diajarkan namun dikembangkan dan dilaksanakan. Pada berbagai kegiatan belajar di kelas, kampus maupun di luar kampus seperti kegiatan ekstrakurikuler serta kegiatan lain perlu dilaksanakan penanaman nilai-nilai karakter. Strategi pengintegrasian pendidikan karakter dalam program yang telah direncanakan oleh program studi serta organisasi mahasiswa merupakan langkah penerapan pendidikan karakter melalui kegiatan rutin, spontan, keteladanan serta pengkondisian.

Sebagaimana program pemerintah era Presiden Joko Widodo yang memprioritaskan penguatan pendidikan karakter di semua elemen, tentunya sangat dibutuhkan sinergisitas, komitmen serta keteguhan prinsip dalam menjalankan dan membangun pondasi dasar sebuah pendidikan yang secara hakikat tidak hanya sekedar transfer of knowledge, akan tetapi transfer ofvalue yang dijewantahkan pada luaran yang diharapkan sebagai generasi yang cerdas dan juga benar.

\section{SIMPULAN}

Berdasarkan analisis data dari penelitian yang dilakukan serta mengacu pada perumusan masalah pada penelitian ini, dapat disimpulkan beberapa hal sebagai berikut. 1) Calon guru matematika merencanakan pendidikan karakter dengan baik dan diinternalisasi dalam kurikulum KKNI serta dirancang sesuai dengan indikator-indikator yang ada pada panduan SNP-PT. 2) Calon guru matematika melaksanakan pendidikan karakter dengan baik walaupun belum secara keseluruhan dikarenakan terdapat kendala di dalam penanaman pendidikan karakter seperti waktu yang sedikit dalam penanaman karakter khususnya terkait dengan beban SKS perkuliahan yang harus diiringi pendidikan karakter saat mengajar di kelas. 3) Calon guru matematika menilai pendidikan karakter dengan sangat baik sebagai perbaikan karakter di lingkungan prodi. Oleh sebab itu penilaian pendidikan karakter dilaksanakan di dalam semua aspek akademik maupun administrasi serta di dalam maupun di luar kelas, baik melalui pertemuan formal maupun non formal yang diskenario dalam program rutin dan nonrutin Prodi maupun Ormawa.

\section{DAFTAR PUSTAKA}

[1] Jihad, A., \& Haris, A. Evaluasi Pembelajaran. Yogyakarta: Multi Pressindo. 2013.

[2] Manalu, J.M.H. "Pendidikan Karakter terhadap Pembentukan Perilaku Mahasiswa (Studi Kasus Proses Pendidikan Karakter dalam HMJ Sosiolog Universitas Mulawarman Kal-Tim)". eJournal Psikologi.Vol. 2, no.4, hlm. 26-38. 2014.

[3] Chrisiana, W. "Upaya Penerapan Pendidikan Karakter bagi Mahasiswa (Studi Kasus di Jurusan Teknik Industri Uk Petra)". Jurnal Teknik Industri. Vol. 7, no.1, hlm. 83-90. 2005.

[4] Susanti, R. "Penerapan Pendidikan Karakter di Kalangan Mahasiswa". Jurnal Al-Ta'lim. Jilid 1, no.6, hlm. 480-487. 2013.

[5] Khusniati, M. "Pendidikan Karakter Melalui Pembelajaran IPA". Jurnal Pendidikan IPA Indonesia.Vol. 1, no.2, hlm. 204-210. 2012.

[6] Sugiyono. Metode Penelitian Pendidikan Pendekatan Kuantitatif, Kualitatif, dan R\&D. Bandung: Alfabeta. 2013. 